\title{
The Future of the Witness: Nature, Race and More-than-Human Environmental Publics
}

\author{
SHELA SHEIKH \\ Media, Communications and Cultural Studies, Goldsmiths, University of London
}

\section{Introduction}

In a 2014 article entitled 'Ecology, Race, and the Making of Environmental Publics: A Dialogue with Silent Spring in South Africa, anthropologist Lesley Green identifies obstacles to the creation of an 'environmental public' in contemporary post-apartheid South Africa. ${ }^{1}$ The broader backdrop against which Green writes - one that is experienced globally to differing degrees and often in distinct manners - is that of environmental violence that is enacted both against racialised human bodies and against nature, and, with this, the entanglement between abuses of human and nonhuman rights. For a start, violations of human rights, in South Africa and beyond, have been and often continue to be carried out through the natural environment, using scorched-earth tactics, environmental remodelling, industrial-scale agriculture, the creation of enclosures, ${ }^{2}$ dispossession through land-grabbing, and so on. Moreover, in the context of 'environmental racism', such violations are often enacted against racialised populations who are rendered culturally and politically 'disposable' or 'sacrificeable'. Included here are climate refugees or, in the case of contemporary South Africa, those denied access to potable water, exposed to higher levels of pollution and/or toxicity, or removed from their land to enhance the profitability of extractive capitalism - such as mining - or, more sinisterly, removed from their land in the name of conservation. ${ }^{3}$

\footnotetext{
I am grateful to the two anonymous reviewers for their insightful comments on an earlier version of this article.

1 L. Green, 'Ecology, Race, and the Making of Environmental Publics: A Dialogue with Silent Spring in South Africa', Resilience: A Journal of the Environmental Humanities, 1, 2 June 2014, unpaginated, https://muse.jhu.edu/article/565696/pdf (accessed 1 November 2018). As suggested by the title, Green's article is a reading of Rachel Carson's seminal 1962 book, Silent Spring, in the context of contemporary environmental debate in South Africa.

2 In the South African context, the planting of a wild almond tree hedge in 1660, parts of which are still evident in Kirstenbosch National Botanical Gardens in Cape Town, is a prime example. In the words of Uriel Orlow, 'the planting of [this hedge] to protect the fruit and vegetables from the grazing cattle of the KhoiKhoi can be considered as one of the first acts of violence against the indigenous population.' U. Orlow, 'Preface: Beautiful, But Dangerous' in S. Sheikh and U. Orlow (eds), Uriel Orlow: Theatrum Botanicum (Berlin: Sternberg Press, 2018), 21-23; see also M. Boehi, 'Multispecies Histories of South African Imperial Formations in the Kirstenbosch National Botanical Garden' in Sheikh and Orlow, Theatrum Botanicum, 81-87, esp. 84.

Regarding scorched earth tactics, and accompanying attempts to criminalise ecocide, see P. Tavares, 'The Geopolitical Imperative: On the Political Ecology of the Amazonia's Deep History' in E. Turpin (ed.), Architecture in the Anthropocene: Encounters Among Design, Deep Time, Science and Philosophy (Ann Arbour: Open Humanities Press, 2013), 209-239, esp. 229-231; and H. Meszaros-Martin, 'Defoliating the World: Ecocide, Visual Evidence and "Earthly Memory"', Third Text, 32, 2-3, Spring 2018 230-253.

Regarding violence enacted through the environment, see R. Gray and S. Sheikh, 'The Wretched Earth: Botanical Conflicts and Artistic Interventions - Introduction', Third Text, 151, 32, 2-3, Spring 2018, 163-175, at 164; U. Orlow and S. Sheikh, 'Introduction: A Prisoner in the Garden' in Sheikh and Orlow, Theatrum Botanicum, 25-39, esp. 28.

3 Regarding this 'disposability' and 'sacrificeability', see J. Butler, Frames of War: When Is Life Grievable? (London: Verso, 2010), N. Klein, 'Let Them Drown: The Violence of Othering in a Warming World', London Review of Books, 38, 11, 2 June 2016, http:// www.lrb.co.uk/v38/n11/naomi-klein/let-them-drown (accessed 1 November 2018). On environmental racism, see F. Vergès, 'Racial Capitalocene: Is the Anthropocene Racial?' Verso Blog, 30 August 2017, https://www.versobooks.com/blogs/ 3376-racialcapitalocene (accessed 1 November 2018).
} 
In the case of the environment, Green speaks of the 'political silence ... of creatures and landforms that we call "nature"." 4 In one of the key gestures that I set out to examine in relation to the condition of 'missingness', nature is treated as an object, 'a resource without voice or rights. ${ }^{5}$ Moreover, nature is treated as an object that needs to be protected by humans, but only certain kinds of humans. For instance, as Green relates, in the context of the 'tragedies' of 'compliance-based environmental management' in South Africa, nature, so the dominant story goes, needs to be protected by the government from those who supposedly have no right to it (for example, poachers or Asian syndicates) for those who 'do' have the rights to it (such as quota holders and conservation scientists). This question of who is entitled or ought to speak in the name of whom is one of my key concerns in what follows. The question is considered in the context of silencing and missingness, as well as constructed categories of active/passive, subject/object as these play out across race, nature and shifting conceptions of the human.

In South Africa, Green writes, the question of who has the right to advocate for nature is 'profoundly racialized, since voices raised in the protection of nature have an uneasy time escaping the scripts of race and racism.' Key here is the subject/ object relation that, as I come to below, must be read through the legacy of colonial categorisations of forms of life. As Green writes: 'The violence that is racism ... finds its power in the classification of some as subjects, who have the right to speak, and others who are silent. The silenced are but objects or things in the racial imaginary in which people are reduced to the non-human; classed as a lesser species ${ }^{7}$ - and, ironically, as closer to 'nature.'

In the context of this special issue on the theme of 'Missing and Missed: The Subject, Politics and Memorialisation of South Africa's Colonial and Apartheid Dead', my contribution may at first appear somewhat oblique. For a start, beyond my reference to Green's article, I write neither from South Africa, nor of its colonial or apartheid history and legacies. Rather, like many of the contributors, I respond to the aim of both this special issue, and the workshop that preceded it, to take insights from the unique status of 'missingness' in the South African context in order to engage with a multitude of geopolitical settings. (My reading moves, via South Africa, from the European Holocaust to global humanitarian and forensic practices, through largely European and North American science and technology studies, as well as Amerindian thinking, to gather a generalised set of questions and propositions). I take Green's analysis of the specificity of environmental publics in South Africa as a

Green, 'Environmental Publics'.

Green, 'Environmental Publics', emphasis added.

Green, 'Environmental Publics'. Otherwise put, 'in a context in which conservation is increasingly implemented at the point of a gun or at least at the point of booms that open only to paying elites, the legacy of racism spills out like oil from a sunken ship'. Green writes of the exorbitant cost of entry to South Africa's national parks, which, given the country's 'skewed economic categories', excludes racialised sections of the population.

7 Green, 'Environmental Publics'. On the classification of people along racial lines as 'less-than-human' and 'not-quite-human', see A. G. Weheliye, Habeas Viscus: Racializing Assemblages, Biopolitics, and Black Feminist Theories of the Human (Durham, NC: Duke University Press, 2014).

8 This is particularly the case for indigenous populations in settler colonial contexts. 
provocation to think through a particular kind of 'missing figure': that of the witness, albeit in an expanded sense, and on a global scale.

\section{The witness as missing figure}

The missing figure to whom or which I refer here is not the missing witness as the object of past colonial or apartheid violence - the figure who has been stripped, precisely, of their status as subject or person, dehumanised and disappeared (or made missing), ${ }^{9}$ and who is thus no longer able to speak and testify to their fate, be this to a legal court or to the court of public opinion or history. Nor is this the witness figure as survivor (the witness as superstes) or onlooker (the witness as third party or testis) who gives testimony to public, quasi-legal hearings about what took place. ${ }^{10}$ (The hearings that were part of South Africa's Truth and Reconciliation Commission are one example, but global examples abound.) Rather, responding to both Green's reading of contemporary environmental publics and to the broader escalation of environmental violence on a global scale, the missing figure here designates the very manner in which we conceive of the witness, ontologically (across various forms of life and temporalities), epistemologically and politically. Read through the grammar of the double genitive, my title, 'The Future of the Witness', is intended to provoke two questions. First, in what ways must we re-conceptualise and expand our understanding of 'the witness' as we move into the future? Second, is it possible for a witness to testify to both present and future experiences - to the very future of life on this planet that is threatened through the ever-escalating Anthropocenic environmental violence that I have begun to outline above? ${ }^{11}$ As such, witnessing in this context is not the act of bearing witness (testifying) in the present to an event that took place (was witnessed or experienced) at a determined moment in the past. Rather, unlike the classical conception of testimony in which the 'thing' experienced is no longer present to the witness, and as such is recalled through memory, witnessing is here conceived of as an ongoing process that entails the simultaneous registration (witnessing) of experiences and representation (bearing witness) to a public. In this context, witnessing is understood as an accumulation of grievances in the context

9 To this missingness, we can add what Jenny Edkins names 'unmissing', as in simply not noticed, at least by some, as missing. J. Edkins, Missing: Persons and Politics (Ithaca, NY and London: Cornell University Press, 2011), 5.

10 These figures have been amply documented and engaged with by scholars embedded in the South African context, for instance from the perspectives of history, literary theory, philosophy, and law, to name but a few, and in the work done in the Forensic History Project based in the History Department at the University of Western Cape.

The word 'witness' has two roots in Latin (and, as Émile Benveniste shows, in all Indo-European languages): on the one hand, testis, someone who was present as a third party (from terstis) at a transaction where two persons are concerned; and superstes, someone who 'exists beyond' the event, who experienced it and survived it in order to subsequently bear witness. É. Benveniste, Indo-European Language and Society 1969 (London: Faber, 1973). See D. Fassin, Humanitarian Reason: A Moral History of the Present, R. Gomme (trans.) (Berkeley, Los Angeles, London: University of California Press, 2012), 204; S. Krämer and S. Weigel, 'Introduction: Converging the Yet-Separate Theoretical Discourses of Testimony Studies' in Krämer and Weigel (eds), Testimony/ Bearing Witness: Epistemology, Ethics, History and Culture (London: Rowman and Littlefield, 2017), ix-xli, at xi; and J. Derrida, 'Poetics and Politics of Witnessing', in T. Dutoit and O. Pasanen (eds), Sovereignties in Question: The Poetics of Paul Celan (New York: Fordham University Press, 2005), 65-86, at 73-74.

11 The term Anthropocene designates the 'human dominance of biological, chemical and geological processes on Earth'. See P. J. Crutzen and E. F. Stoermer, 'The "Anthropocene", International Geosphere-Biosphere Programme Global Change Newsletter 41, $2000,17-18$. 
of environmental degradation and the subjugation of certain 'subjects' (be these human or nonhuman). ${ }^{12}$

My argument is that, where collective action and responses are demanded, insofar as singular lives are violated within broader ecologies, the witness can no longer be a solitary figure; rather, the witness must instead be but one within a collectivity. Moreover, it is precisely in the context of a collectivity that the witness figure of which I write is constituted and produced. No longer the heroic, autonomous individual, the witness must be one of many, inscribed within a particular social milieu. As Sybille Krämer and Sigrid Weigel stress, despite the lack of agreement regarding concepts of, and approaches towards, testimony, at least one 'fundamental consensus' exists: namely, that testimony cannot be determined outside of a 'testimony constellation' or 'social constellation'. Thus, "testimony"/"bearing witness" is a relational concept ... an intersubjective situation in a historically specific social world that is condensed in the act of testifying. ${ }^{13}$

Furthermore, although the figure of the witness has traditionally been confined to the human (particularly in the legal realm), I argue that, where care for both human and nonhuman life is at stake, witness collectivities necessarily entail an expansion beyond the category of the human. In other words, that such collectivities might be more-than-human, with this term signalling an entanglement between humans and nonhumans (or 'other-than-humans'), and a form of sociality that, in the words of Anna Tsing, 'does not distinguish between human and not human. ${ }^{14}$ Green argues for an environmentality that does not take recourse to modernist categories of subject and object - the categorisation that I began to sketch out above, and which, as I explain below, forms the basis of the construction of 'humanity' and 'nature' as well as race. ${ }^{15}$ In other words, although Green does not use this specific term, I argue that what she calls for is an environmental public that entails 'more-than-humans'. What I propose is that we extend Green's thesis and conceive of the figures that constitute such a public more specifically as active witnesses, across the human/nonhuman divide, to present both unfolding environmental degradation and possible more liveable futures.

What I take from Green's reading of the South African context is the need to surpass the argument around the naturalisation of race as a social construct (for instance, in the othering of indigenous peoples, whose representations, from without, place them closer to an exotic nature; or the rendering 'disposable' of racialised populations merely through a cultural imaginary) and to instead address both race and nature concomitantly in the modernist imaginary. This can be done precisely through

12 For a reading of the conventional temporal and sense-perceptual schema of witnessing/testimony, see Derrida, 'Poetics and Politics of Witnessing', 77.

13 Krämer and Weigel, 'Introduction', $x$.

14 'Nonhuman' here is taken to define everything other than human in relation to the human, unlike 'more-than-human', which encompasses both human and nonhuman. On 'more-than-human sociality' as forms of sociality made 'with or despite clearly human formulated intentions', see A. Tsing, 'More-than-Human Sociality: A Call for Critical Description' in K. Hastrup (ed.), Anthropology and Nature (New York and London: Routledge, 2013), 27-42, esp 28. See also A. Tsing, The Mushroom at the End of the World: On the Possibility of Life in Capitalist Ruins (Princeton and Oxford: Princeton University Press, 2015).

Green, 'Environmental Publics'. 
the manner in which the subject/object divide allows us to think through both racism and the war on nature.

Green turns to the constitution writers of contemporary Ecuador and Bolivia who, by including nature as bearer of legal rights in 2008, 'have extended their critique of modernist thought to reject the subject-object divide that legitimates a war on nature', and 'are attempting to constitute an environmentality that draws on a different intellectual heritage - one that is deeply bound up in Amerindian thought. ${ }^{\prime}{ }^{16}$ While Green's move is to bring the South African post-apartheid experiment into conversation with that of Latin American decoloniality (which I return to below), I suggest that these two 'experiments' offer much when we rephrase environmental publics through the language of witnessing, especially when conceived in terms of subject and object and, as I am coming to, classical and persistent postcolonial questions of representation.

To be clear, I am not the first to propose that the figure of the witness be extended beyond the human. I take leave from a range of reconceptualisations of the witness, beyond the human, to frame these in the context of witnessing collectivities, and then focus on some specific questions around missingness and representation that I argue require further consideration. As such, what follows contributes to an as yet dispersed field that traverses multiple disciplines and geographical locations. In the legal context, practices and theorisations of nonhuman rights or the rights of nature - and, with this, shifting categories of personhood, legal standing and voice - have done much to acknowledge nature as 'a fundamental space to which cultural and political rights are bound' and to make 'ecological systems inhabit the courtrooms of national and transnational forums as potential witnesses of legal violations. ${ }^{17}$ There are notable further examples of expanding the category of the witness beyond the 'human'. For instance, deconstruction (notably in the work of Jacques Derrida) had already shown us that the irreplaceable, sovereign, autonomous and self-present figure that the witness is supposed to be is always already affected by heteronomy, and prosthetised by an 'originary technicity', as such exposing the impossibility of 'pure', 'actual' or 'authentic' testimony. ${ }^{18}$ And if human testimony can be seen as always already quasi-technologised, and as such never fully 'human' (in the sense of pertaining to physis, as opposed to its supposed opposite, tekhne), on the seeming other end of the spectrum, technological media might itself be considered as witness.

16 Green, 'Environmental Publics'.

17 P. Tavares, 'Nonhuman Rights' in Forensic Architecture (eds), Forensis: The Architecture of Public Truth (Berlin: Sternberg Press, 2014), 553-572, at 562. The literature on the rights of nature is vast. For a useful overview, see T.J. Demos, 'Rights of Nature: The Art and Politics of Earth Jurisprudence, April 2015, https://cpb-us-e1.wpmucdn.com/sites.ucsc.edu/dist/0/196/files/2015/10/ Demos-Rights-of-Nature-2015.compressed.pdf (accessed 1 November 2018); and R. Youatt, 'Personhood and the Rights of Nature: The New Subjects of Contemporary Earth Politics', International Political Sociology, 11, 1, 2017, 1-16.

18 In other words, the (self-same) 'presence' of human speech (for testimony, in theory at least, should be proffered 'live', in the first person and without any technological recording or transmission devices) is only possible on the basis of a quasi-technical reproducibility that for Derrida 'is' the minimal trace of both communicability and experience per se. Notable texts by Derrida on witnessing include: 'Poetics and Politics of Witnessing'; Monolingualism of the Other; or, The Prosthesis of Origin, P. Mensah (trans.) (Stanford, CA: Stanford University Press, 1998); Demeure: Fiction and Testimony, E. Rottenberg (trans.) (Stanford, CA: Stanford University Press, 2000); J. Derrida and B. Stiegler, Echographies of Television: Filmed Interviews, J. Bajorek (trans.) (Cambridge: Cambridge, NY: Polity Press, 2002). 
Here the work of Susan Schuppli is instructive. Since 2005, through both art practice and theoretical writings, Schuppli has been developing the 'material witness' - an operative concept that foregrounds the 'expressive' quality of nonhuman matter, and demonstrates how media artefacts and environmental conditions themselves bear witness not only to 'events' but also the sorting and registration processes imposed upon them in order for them to qualify as evidence in the first place. In other words, the material witness, ordinarily the legal term for someone who has knowledge pertinent to a criminal act or event that could be significant for the outcome of a trial, here refers to both 'the evidence of the event' and 'the event of evidence. ${ }^{19}$ Schuppli also asks 'how objects become agents of contestation between different stake-holders and truth claims, ${ }^{20}$ especially in the manner in which they are 'made to speak' as technical witnesses to crimes. A further significant reference point is 'forensic aesthetics', upon which the work of London-based Forensic Architecture is premised. ${ }^{21}$ Forensic Architecture is a research agency established in the context of the fallibility or absence of human testimony. ${ }^{22}$ In the absence of reliable human witnesses (that is, when the witness is missing), forensic architecture, to which I will return, turns to the agency of matter (organic or inorganic, including natural environments) or 'object witnesses' to question factual reality as expressed by state agencies.

Where the rights of nature and the practice of forensic aesthetics are oriented towards evidentiary and legal forums, the witness-collectivities to which I gesture also operate beyond empirical truth claims in the sphere of public opinion more broadly. In what follows, I examine the capacity of nature to register empirically and express environmental change. I also take inspiration from the work of political theorist Michal Givoni. Givoni's reading of the specific form of humanitarian witnessing practiced by Médecins Sans Frontières (MSF, or Doctors Without Borders), as described in her book, The Care of the Witness: A Contemporary History of Testimony in Crisis, provides a blueprint for conceiving of witnessing as both a practice of care for the other, and of political protest that contests contemporary (neoliberal, neo-colonial and extractivist) forms of governmentality. ${ }^{23}$ However, where Givoni's witness bears witness primarily to humanitarian disasters, I argue for the necessity of moving beyond the human.

See, S. Schuppli, 'Dark Matters: An interview with Susan Schuppli', by L. van der Velden and R. Menkman, http://www. darkecology.net/dark-matters-an-interview-with-susan-schuppli (accessed 25 November 2018).

20 See Material Witness, https://www.forensic-architecture.org/file/material-witness/ (accessed 1 November 2018).

21 Schuppli was senior research fellow and project coordinator on the Forensic Architecture project from 2011 to 2014.

22 The group - which is comprised of architects, theorists, lawyers, scientists, programmers, artists and filmmakers - gathers and presents spatial analysis in legal and political forums across the world, with the aim of using the investigative apparatuses of the state against the state, above all in respect to its violations, in chime with the model of nongovernmental politics to which I will turn. 'Architecture' here is both used in a restricted sense (that is, buildings, which are viewed as documentary forms or sensors), and as a field of knowledge and a mode of interpretation, concerned with relations between people and things, through spaces and structures - from the human body, through buildings and homes to the planet itself, which is proposed as the ultimate home or 'construction site'. See https://www.forensic-architecture.org; T. Keenan and E. Weizman, Mengele's Skull: The Advent of a Forensic Aesthetics (Berlin: Sternberg Press, 2012); E. Weizman, 'Introduction: Forensis' in Forensic Architecture (eds), Forensis: The Architecture of Public Truth (Berlin: Sternberg Press, 2014), 9-32; and E. Weizman, Forensic Architecture: Violence at the Threshold of Detectability (New York: Zone Books, 2017). Of particular relevance here are the group's investigations into environmental violence; see, for instance, Forensic Architecture in collaboration with SITU Research, 'Case: Guatemala' in Forensic Architecture, Forensis, 519-552.

23 M. Givoni, The Care of the Witness: A Contemporary History of Testimony in Crises (Cambridge: Cambridge University Press, 2016). 
In considering nature as active participant in environmental publics, I do not propose that nature be conceived as witness figure strictly speaking, insofar as this would entail anthropomorphism - for instance, that nature can bear witness linguistically, or be conceived as witness in the framework of trauma studies, memory studies, ethics, affect theory or psychoanalysis that are entailed within testimony theory. ${ }^{24}$ Rather, my argument is that witnesses are produced in the context of more-thanhuman socialities, between the human and nonhuman. In the case of nonhuman life, I question whether our vocabulary must be expanded beyond the term 'witness', with all its anthropocentric assumptions.

It is with this risk of anthropocentrism, in particular, that what follows adds a specific line of enquiry to existing conceptions of the witness figure beyond the human. While the discourse of the rights of nature, and its 'vocative moment', has been debated in terms of the risks entailed in 'giving voice' to nature, ${ }^{25} \mathrm{I}$ phrase this here in terms of the paradoxical risks entailed in retrieving missing figures. In contexts in which the witness is missing (that is, absent and, for some at least, missed), should not a prosthetic or proxy testimony be sought? How, then, to grapple with the problematics of 'speaking for', or in lieu of, the missing or missed, insofar as this runs the risk of reinforcing an original silencing or effacement through the category of nature or race, for instance? Or, in the context of environmentalism, when this entails the possibility of nature itself becoming the subaltern, deprived of an adequate audience? In other words, in what follows, I wish to 'stay with the trouble' (to use Donna Haraway's phrase), by acknowledging the ambiguities and potentially productive limitations to witnessing. ${ }^{26}$ That is, if the 'era of the witness' - a foregrounding of the testimonial narratives of victims that took place notably after the trial of Adolph Eichmann in 1961 - was paradoxically premised upon the troubled performance of testimony (and, in fact, upon a crisis of testimony), ${ }^{27}$ what might be the productive ambiguities of both witnessing and representational practices in an age in which nature - previously overlooked or missed in the imaginary of modernity, as passive object - is granted both legal rights and expressive capacities?

\section{The care of the witness: between ethics and politics}

'No one / bears witness for the / witness. ${ }^{28}$ Such are the oft-quoted words of the poet Paul Celan, whose body of work exemplifies the impossibility of testifying to the horrors of the Nazi camps. ${ }^{29}$ This line functions simultaneously as an ethical injunction:

24 For useful overviews of these varying approaches to testimony theory, see Givoni, Care of the Witness; and Krämer and Weigel, Testimony/Bearing Witness.

25 I take the term 'vocative moment' from Green, 'Environmental Publics'. Critics of the rights of nature 'include both humanists who are skeptical of the way that speaking for nature is a front for other human interests, and posthumanists who worry about the re-institution of an anthropocentric politics in the act of "speaking for" nonhumans.' Youatt, 'Personhood and the Rights of Nature', 2.

26 See D. Haraway, Staying with the Trouble: Making Kin in the Chthulucene (Durham, NC: Duke University Press, 2016).

27 See Givoni, Care of the Witness, 5.

28 P. Celan, 'Aschenglorie' in Atemwende (Frankfurt a. M.: Suhrkamp, 1967), 68; English trans. J. Neugroschel as 'Ash Glory' in Celan, Speechgrille and Selected Poems (New York: Dutton, 1971), 240.

29

See Derrida, 'Poetics and Politics of Witnessing.' 
that no-one should bear witness in the place of the witness, that no-one should speak for the witness - a quandary that is central in what follows in relation to nature. And yet, as Giorgio Agamben writes, the witness as survivor (superstes) does not testify fully, for the 'true' or 'complete' witness is the drowned (the 'Muselmann'), who 'touched bottom' and for whom no-one can testify or stand in as a third-party witness (testis) or 'spokesperson. ${ }^{30}$

As Didier Fassin writes, 'in current usage, the boundary between the figures of superstes and testis 'is tending to become blurred. ${ }^{31}$ The superstes has come to be supplanted by the testis in manifold ways, most notably nowadays, as Eyal Weizman notes, 'with the development and widespread accessibility of digital data derived from activist imagery and their accelerated dissemination via mobile-phone, cloud, and social networks. ${ }^{32}$ Looking back, this shift can be read in tandem with the emergence of the humanitarian witness, propelled by the work of Médecins sans Frontières (MSF), which 'was born in 1971 out of the refusal to remain silent during the war in Biafra.' Thus emerged the witness as testis: 'not the witness who has experienced the tragedy, but the one who has brought aid to its victims. ${ }^{33}$

Here I linger a while with Givoni, in an attempt to bring into dialogue her thesis regarding 'the care of the witness', and the problematics of 'speaking for' in the context of environmental violence. Givoni's starting point in The Care of the Witness is a study of the internal dilemmas and debates regarding humanitarian witnessing within MSF that culminated in the publication and dissemination of a series of studies entitled 'Speaking Out' in $2004 .{ }^{34}$ What the series' reflexive elaboration on witnessing, memory and advocacy confirmed was that the humanitarian witness was not just a source of eye-witness testimony but also a character to take on - one who pursues outspoken statements to be carefully deliberated within (largely Western, admittedly) public, political spheres. ${ }^{35}$ The re-conceptualised task of witnessing was premised upon more than simply 'speaking truth to power'; rather than seeking simply to contest power (and neoliberal governmentality in particular), it also strove to provide acts of care. ${ }^{36}$ By drawing from Michel Foucault's notion of ethics as a reflective and socially guided 'care of the self', ${ }^{37}$ through her reading of MSF, Givoni argues that the cultivation of the self is not incompatible with a politics that underscores responsibility towards, or care for, the other. ${ }^{38}$

"The survivors speak in their stead, by proxy, as pseudo-witnesses; they bear witness to a missing testimony ... Whoever assumes the charge of bearing witness in their name knows that he or she must bear witness in the name of the impossibility of bearing witness.' G. Agamben, Remnants of Auschwitz: The Witness and the Archive, D. Heller-Roazen (trans.) (New York: Zone Books, 1999), 34. Here Agamben is commenting upon Primo Levi's experience of Auschwitz as depicted in Survival in Auschwitz and The Reawakening: Two Memoirs, Stuart Woolf (trans.) (New York: Summit Books, 1986).

31 Fassin, Humanitarian Reason, 205.

32 Weizman, 'Introduction: Forensis', 12.

33 Fassin, Humanitarian Reason, 205-206. See also Givoni, Care of the Witness, 2.

34 Givoni, Care of the Witness, 3-4.

35 Givoni, Care of the Witness, 176.

36 Here witnessing and testimony are gestures that do not just produce empirical or metaphysical truths; rather, they 'are bound to instigate a subjective transformation'. Givoni, Care of the Witness, 11.

37 Givoni draws from M. Foucault, The Use of Pleasure (New York: Vintage Books, 1990), esp. 25-32; and M. Foucault, The Hermeneutics of the Subject: Lectures at the Collège de France, 1981-1982, Frédéric Gros (ed.) (New York: Palgrave Macmillan, 2005).

Givoni, Care of the Witness, 206, $175 \mathrm{ff}$. 
Here, the troubled performance of testimony that constituted the 'era of the witness', and that had been consolidated by the poststructuralist tradition as 'the tenacious trace of humanity in politics, ${ }^{39}$ is combined with a more explicitly activist take: where poststructuralist theory stressed the bankruptcy of ethics to the detriment of the political challenges of witnessing, and where subsequent studies focused on the political instrumentality of witnessing but neglected the ethical, Givoni identifies a combination of the two in the work of MSF. Here, then, is the entrance of the stillethically concerned, reflexive witness into the sphere of politics.

While Givoni's concern is humanitarian witnessing, as practiced and developed by MSF, her use of Michel Feher's account of nongovernmental politics, and the 'shared determination not to be governed thusly', ${ }^{40}$ has much to offer for the context of environmental activism as a means of protesting a mode of governing premised upon the assumption that individuals fulfil their political and civic obligations best 'when they seek to fulfil themselves as free individuals."41 Givoni's aim is to bring into focus the interplay between witnessing and the contemporary logic of governing by 'responsibilization. This includes the transformation of liberal democracies from interventionist apparatuses to ones in which individuals are propelled to act socially and responsibly out of their own initiative. In the context of environmental justice, the point has been made repeatedly that, whereas supranational binding agreements on quotas to tackle climate change (and thus reduce numbers of climate refugees), combined with adequate state policy, are necessary, ${ }^{42}$ neoliberal governmentality increasingly seeks to place responsibility on individuals (often as 'green consumers'). ${ }^{43}$

In Givoni's account, witnessing, as practiced by MSF, is a means to a 'moral crafting of the self' that avoids creating 'anchors for neoliberal policy that transfers responsibilization to private individuals in matters pertaining to both global and social justice. ${ }^{\prime 4}$ That is, witnessing is a means of 'defying neoliberalism from within ${ }^{35}$ that does not simply '[denounce] and [lament] the personalization of politics as the strategy through which neoliberalism causes people to lose sight of their collective interests. ${ }^{46}$ Rather, the practice of witnessing, as a simultaneous cultivation of the self, and caring for others via an active participation in political life, allows for strategies of self-cultivation that can be regarded as 'a way of relaunching the politicization of the personal ${ }^{47}$ - a means for citizens 'to carve out for themselves new avenues for public

39 Givoni, Care of the Witness, 5. Givoni focuses on the figure of the witness in the work of Jean-François Lyotard, Giorgio Agamben and Shoshana Felman.

40 Givoni, Care of the Witness, 28, 25-26, emphasis in original. See also M. Feher, 'The Governed in Politics' in M. Feher, G. Krikorian and Y. McKee (eds), Nongovernmental Politics (New York: Zone Books, 2007), 12-27.

41 N. Rose, Powers of Freedom: Reframing Political Thought (Cambridge: Cambridge University Press, 1999), 166, cited in Givoni, Care of the Witness, 24.

42 See A. Lahoud, 'Floating Bodies' in Forensic Architecture, Forensis, 495-518.

43 See for instance M. Lukacs, 'Neoliberalism has conned us into fighting climate change as individuals', Guardian, 17 July 2017 , https://www.theguardian.com/environment/true-north/2017/jul/17/neoliberalism-has-conned-us-into-fighting-climatechange-as-individuals (accessed 1 November 2018).

44 Givoni, Care of the Witness, 25.

45 M. Feher, 'Self-Appreciation; or, The Aspirations of Human Capital', Public Culture, 21, 1, 2009, 21-41, at 21, cited in Givoni, Care of the Witness, 26.

46 Feher, 'The Governed in Politics', 38, cited in Givoni, Care of the Witness, 26.

47 Feher, 'The Governed in Politics', 38, cited in Givoni, Care of the Witness, 26. 
action beyond those already prescribed in official politics. ${ }^{48}$ An example of this is the citizen-science environmental-sensing project that I outline below.

\section{The future of the witness: beyond the human}

In the context of contemporary environmental violence, with its roots in colonialism and the plantation system, there is increasing awareness that practices of more-thanhuman 'world-making' that entail more-than-human planetary subjects, are needed. ${ }^{49}$ Givoni's witnesses, for all their worth, remain within the realm of the humanitarian, tasked with rescuing a certain 'humanity' who face 'inhuman' horrors. ${ }^{50}$ The question remains as to how the more-than-human might figure within this constellation. Before turning to this, let us linger on the temporality of witnessing.

As mentioned, in contexts of environmental risk, what must be borne witness to is not something that has occurred in the past; rather, it is often a present, ongoing violence that is likely spill over into the future. Given the realities of Anthropocenic extinction, depletion and degradation, such violence makes itself felt pre-emptively in the present. ${ }^{51}$ And besides, this temporal expansion is also a question of perceptibility. If Givoni's concern is to 'critically examine the applicability of the poststructuralist concept of witnessing to contemporary catastrophes' and to question what it means to 'be a witness to emergencies, ${ }^{52}$ we might also ask: i) how to bear witness to a 'catastrophe' or 'emergency' that remains largely imperceptible; ii) on whose scale does an 'emergency' register when the emergency is the slow annihilation of a liveable and 'sustainable' environment - the slow collapse of ecosystems that leaves bodies facing a suffocating future that, in many cases, involves the quite literal annulment of their world.

Here I turn to Rob Nixon's Slow Violence and the Environmentalism of the Poor, which I propose we reread explicitly from the perspective of witnessing. ${ }^{53}$ What Nixon terms 'slow violence' escapes the spectacle-driven corporate media and our flickering attention spans. ${ }^{54}$ Typically not even perceived as violence, slow violence is not time- or body-bound, but rather attritional and delayed in its effects. ${ }^{55}$ Most often

49 Many have made strong claims for the Anthropocene needing to be understood through the colonial plantation system (hence Donna Haraway's term 'Plantationocene'). See D. Haraway, 'Anthropocene, Capitolocene, Plantationocene, Chthulucene: Making Kin', Environmental Humanities, 6, 2015, 159-165; Vergès, 'Racial Capitalocene', Gray and Sheikh, 'The Wretched Earth'. Regarding more-than-human 'planetary subjects', see J. Gabrys, 'Becoming Planetary', e-flux architecture, 2 October 2018, https:// www.e-flux.com/architecture/accumulation/217051/becoming-planetary/ (last accessed 25 November 2018).

50 See Givoni, Care of the Witness, 213.

51 The threat of 'Day Zero' in Cape Town's 2017/2018 water crisis can be read through this temporal logic.

52 Givoni, Care of the Witness, 203.

53 Cambridge, MA: Harvard University Press, 2011.

54 This parsing of slow violence is taken from my entry on 'Violence' in R. Braidotti and M. Hlavajova (eds) The Posthuman Glossary (London: Bloomsbury, 2017), 448-452.

Against the backdrop of the unprecedented fires, floods and heat waves across the globe during 2018, see Nixon's interview with Amy Goodman and Nermeen Shaikh about slow violence: 'Rob Nixon: Gov't Inaction on Climate Change is "Slow Violence" That Hits World's Poor the Hardest', Democracy Now! 2 August 2018, https://www.democracynow.org/2018/8/2/rob_nixon_ govt_inaction_on_climate (accessed 1 November 2018).

Nixon, Slow Violence, 3, 11. 
environmental and everything to do with the 'violent geographies of fast capitalism, ${ }^{56}$ including racism, this insidious violence elides the narrative closure recognisable in visuals of the victory and defeat of war. Instead, it works its way inwards, 'somatized into cellular dramas of mutation that - particularly in the bodies of the poor - remain largely unobserved, undiagnosed, and untreated. ${ }^{57}$ Here, violence must be rethought in the absence of a punctual act, a violent event, ${ }^{58}$ and without a recognisable 'disaster' or 'emergency'. Slow violence is uncapturable - an event that spills over into the future, yet to fully run its course.

Nixon reminds us that many 'humanitarian' disasters are catalysed by humaninduced climate change and by indifference to, or denial of, North American environmentalism's imperial legacies, and contemporary imperial epistemological and extractive violences. Here, the calamitous repercussions of the 'disaster' play out across a range of temporal scales, their invisibility posing a range of representational, narrative and strategic challenges that resonate with the 'missing' as 'overlooked' or 'silenced. ${ }^{59}$ How, then, to create stories and narratives that are 'dramatic enough to rouse public sentiment and warrant political intervention'? ${ }^{60}$ What Nixon calls 'testimonial protest' would involve both 'scientific and imaginative testimony', with Nixon's emphasis being on the latter. Here, the witness is a writer-activist, called upon to draw from literature's 'testimonial and imaginative capacities' to offer 'a different kind of witnessing: of sights unseen. ${ }^{61}$ While my interest is the manner in which definition might be provided by both humans and nonhumans, the potential reconceptualisation of the witness figure necessitates first 'laying bare' certain epistemological and ontological biases that are remnants of the colonial conquest of nature and the categorisation of race.

\section{Nature represents itself}

For Green, one reason why an environmental public has been unable to gather in South Africa is a lack of attention (a blindness, perhaps) to 'the ways in which the logics of coloniality and race continue to inform the idea of nature in South Africa.' ${ }^{62}$ In this context, the decolonial thinking developed primarily in Latin America, as well as the posthumanities, can be mobilised to inform environmental management and conservation science. Epistemologically and ontologically, modernity, as underpinned by coloniality, generated and continues to generate categories of race and nature precisely through its conceptions of subjects and objects:

\footnotetext{
56 M. Watts, Struggles over Geography: Violence, Freedom, and Development (Heidelberg: Dept. of Geography, University of Heidelberg, 2000), 8, cited in Nixon, Slow Violence, 7-8.

7 Nixon, Slow Violence, 6.

58 Lahoud, 'Floating Bodies', 496.

9 See Nixon, Slow Violence, 13.

60 Nixon, Slow Violence, 3.

61 Nixon, Slow Violence, 6, 14, 32, 15.

62 Green, 'Environmental Publics'.
} 
The nature-culture divide is one of the founding dualisms of modernist thought, and it is grounded in the division of subjects from objects ... crucially, the collision of nature and object finds its outworking in racism, for race reduces people to objects via the language of biology and species ... racism naturalizes the idea of race ... [and] turns it into nature. ${ }^{63}$

Drawing from Nelson Maldonado-Torres' critique of modernity in Against War: Views from the Underside of Modernity ${ }^{64}$ in which he engages with the modernist practice of turning some into subjects and others into objects, Green stresses how Western modernity has yet to overcome 'the legacy of dehumanisation that shaped colonialism and racism. ${ }^{65}$ As Rafi Youatt notes, in the context of international politics and the question of who or what can be seen as political actor (or political subject), the making of humanity as a category takes place across lines of race, coloniality, migrants and borders, war, humanitarianism and commodities. ${ }^{66}$ 'Who counts as human at any political moment is itself a byproduct of political life. ${ }^{67}$

Moreover, if the public, specifically the polis, is commonly associated with the human, then the anthropocentrism that is at the heart of colonial and modernist conceptions of politics is yet another blind spot - another form of 'missingness'. For all its attention to the environment and the conjunction between violations carried out against both human and nonhuman life, Nixon's book remains caught within the task of the decidedly human writer-activist rendering slow violence legible or intelligible to human sensibilities. ${ }^{68}$ This is not to criticise Nixon's vastly important book, which has done much to change the discourse within environmental activism and the environmental humanities - and in fact to create, together with notable others, the field that we might now retrospectively name 'postcolonial environmental humanities'), ${ }^{69}$ but rather to signal to and inhabit the uncomfortable aporias of representation that writer-activists face. On the one hand, as mentioned above, 'speaking for' or 'giving voice' to nature runs the risk of anthropocentrism. Likewise, as Astrida Neimanis writes, the warnings sounded by Gayatri Chakravorty Spivak in her seminal 1988 essay, 'Can the Subaltern Speak?', prove as prescient as ever, albeit

63 Green, 'Environmental Publics'. Decolonial feminist María Lugones shows how the modernity/coloniality relation must be understood as fundamentally shaped by race, gender and sexuality; postcolonial and feminist studies of science show how the production of such categories went hand in hand with the categorisation of different forms of life and knowledge in colonial science, particularly the natural sciences, including botanical taxonomy and bioprospecting. See M. Lugones, 'Heterosexualism and the Colonial/Modern Gender System', Hypatia 22 (1) (2007): 186-209; J. Irving, 'Decentering European Medicine: The Colonial Context of the Early History of Botany and Medicinal Plants' in Sheikh and Orlow, Theatrum Botanicum, 129-136; and S. Balani, 'From Botany to Community: A Legacy of Classification' in Sheikh and Orlow, Theatrum Botanicum, 229-235.

64 Durham, NC: Duke University Press, 2008.

65 Green, 'Environmental Publics'.

66 R. Youatt, 'Anthropocentrism and the Politics of the Living' in C. Eroukhmanoff and M. Harker (eds), Reflections on the Posthuman in International Relations: The Anthropocene, Security and Ecology (Bristol: E-International Relations Publishing, 2015), 39-49, at 43.

67 R. Youatt, 'Interspecies Relations, International Relations: Rethinking Anthropocentric Politics', Millennium: Journal of International Studies, 43, 1, 2014: 207-223, at 207 (see also 213-214).

68 Nixon, Slow Violence.

69 For a list of notable references in this field, see Gray and Sheikh, 'The Wretched Earth', 1-2. A starting point for this body of work would be Rob Nixon's, 'Environmentalism and Postcolonialism' in A. Loomba et al. (eds), Postcolonial Studies and Beyond (Durham, NC: Duke University Press, 2005), 233-251. 
relating to different forms of 'subaltern. ${ }^{70}$ In this case, we now see the dangers of 'speaking for' and misrepresenting not only indigenous subjects but also nature. ${ }^{71}$

As Spivak famously asserted, attempts to represent (to speak of or for) the subaltern (in the context of her essay, the Indian woman, or the third-world subject more broadly) are often predicated upon an 'epistemic violence' that '[constitutes] the colonial subject as Other. ${ }^{72}$ Just as Nixon's Slow Violence is a reminder of the role of imperialism in creating the conditions of slow violence in the now global South, Spivak's essay points to the blindness of Western (notably French), poststructuralist thinking regarding the implications of imperialism for this epistemic violence. Furthermore, this is despite the proliferation of attempts to decentre the sovereign subject within poststructuralism; that is, to destabilise the subject as the sovereign agent of intentional acts, on the one hand, and as a transparent, fully legible and un-differentiated object of knowledge on the other. ${ }^{73}$ As Neimanis stresses, the conundrum remains as to whether any form of representation (of humans or nonhumans), however wellintentioned, necessarily involves at least some form of colonisation: a rendering passive or mute, a silencing or secondary 'missingness'. Representation, especially in defence of the rights of nature, remains an 'impossible necessity' - an experience of being trapped between 'a representationalist rock and a hard place of complicit

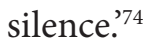

Practically speaking, there are various ways in which we might think through this 'can't yet must' paradox or the 'impossible necessities' of representing nonhumans, to use Neimanis' phrases. ${ }^{75}$ To be clear, Spivak does not suggest that we do away with representation altogether, and in the context of environmental violence this is also not an option. However, representation remains fraught; in Rosalind Morris' parsing,

the subaltern (as woman) at the centre of Spivak's essay describes a relation between subject and object status (under imperialism and then globalization) that is not one of silence - to be overcome by representational heroism but aporia. The one cannot be 'brought' into the other. ${ }^{76}$

I am not suggesting here that nature be 'retrieved' and ushered into the category of subject, but rather that we remain attentive to the possible mechanisms of missingness between the two senses of representation that Spivak reminds us of: 'representation'

70 G. C. Spivak, 'Can the Subaltern Speak?' in C. Nelson and L. Grossberg (eds), Marxism and the Interpretation of Culture (Urbana, IL: University of Illinois Press, 1988), 271-313.

71 A. Neimanis, 'No Representation without Colonisation? (Or, Nature Represents Itself)', Somatechnics, 5, 2, 2015, 135-153. I have previously touched on these points; see S. Sheikh, 'Translating Geontologies' in J. Graham (ed.), And Now: Architecture Against a Developer Presidency: Essays on the Occasion of Trump's Inauguration (New York: Columbia Books, 2017), 165-184. Spivak, 'Can the Subaltern Speak?', 280-281.

73 In the easy claims made by some Western intellectuals that the oppressed are able to 'speak for themselves', the paradox is that the category of the sovereign subject is restored precisely within the theory that sets out to question it. Spivak, 'Can the Subaltern Speak?', 278.

74 Neimanis, 'No Representation without Colonisation?', 136

75 Neimanis, 'No Representation without Colonisation?', 137.

76 R. C. Morris, 'Introduction' in R. C. Morris (ed.), Can the Subaltern Speak? Reflections on the History of an Idea (New York: Columbia University Press, 2010), 1-18, at 13. 
as vertreten (the art of persuasion or rhetoric, as political proxy) and darstellung (tropology, or representation as portrait). ${ }^{77}$

In the context of Forensic Architecture, for instance, ${ }^{78}$ persuasion or rhetorical skill is used to 'ventriloquise' or interpret the 'testimony' of the inanimate in various (legal, political and/or cultural) forums with the aim of constructing 'public truth'. This narration, as a form of advocacy or 'speaking for', 'resembles what the Roman rhetorician Quintilian called prosopopeia - the mediated speech of inanimate objects. ${ }^{79} \mathrm{But}$ 'nature' does in fact represent itself. For a start, we know from nature that vegetal life forms have highly complex means of communication. ${ }^{80}$ Neimanis speaks of nature's capacity to 'write itself', which I suggest we translate into the schema of testimony. For example, she looks to ice and water's capacity to materially register traces, and, as such, 'to destabilise any rigid boundary between nature and culture - one as passive, inert matter there to be consumed and rendered transparent; the other the consumer, the renderer. ${ }^{81}$ As Schuppli's work shows, in particular in the series Slick Images and Nature Represents Itself, environments themselves are expressive: polluted environments, for instance, contain vast photosensitive surfaces that register and record the changes caused by modern industrialisation. ${ }^{82}$ These records can be mobilised by the practice of forensis, which allows the (expert or non-expert) witness (here the testis) to 'read' and narrate such traces in the quest for accountability and exposure. ${ }^{83}$ This recognition of nature's capacity to represent itself - as superstes rather than testis, in the sense of aesthetic representation (darstellen) - is one element of a new politics of political representation as proxy (vertreten). ${ }^{84}$ As architect Godofredo Pereira writes:

Both German words are translatable as 'representation', and Spivak makes much of Michel Foucault and Gilles Deleuze's sliding over the contrast between the two in their readings of Marx's The Eighteenth Brumaire, where he writes that the small peasant proprietors 'cannot represent themselves' (Marx uses vertreten in the original). Spivak's point is that 'the shifting distinctions between representation within the state and political economy, on the one hand, and within the theory of the Subject, on the other, must not be obliterated.' Spivak, 'Can the Subaltern Speak?', 275-276.

78 Forensis is Latin for 'pertaining to the forum', and it is this original, broader sense of the term, prior to the emergence of forensic science, that the group retrieves. See Weizman, 'Introduction: Forensis'.

79 Weizman, 'Introduction: Forensis', 9. Weizman also suggests that 'contemporary modes of prosopopoeia animate material objects or landscapes by converting them into data and image' (10).

80 See for instance, E. Kohn, How Forests Think: Toward an Anthropology Beyond the Human (Berkeley, London: University of California Press, 2015); S. Mancuso, Brilliant Green: The Surprising History and Science of Plant Intelligence, J. Benham (trans.) (Washington: Island Press, 2015).

81 A. Neimanis, 'Nature Represents Itself: Bibliophilia in a Changing Climate' in V. Kirby (ed.), What if Culture was Nature all Along? (Edinburgh: Edinburgh University Press, 2017), 179-198, at 180.

82 In both works, Schuppli analyses the Deepwater Horizon oil spill of 2010 in the Gulf of Mexico, arguing through the artworks and accompanying commentary that the oil slick itself - beyond external images of the spill - '[operationalized] an independent mode of cinema' via what she names a 'slick image. For Schuppli, the cinematic capacity of the oil spill is a feature of 'its very ontology - its molecular structure and behaviour.' As such, the oil slick can be understood as engaged in 'the production of a new form of cinema organised by the found footage of "nature" itself ... The conditions that brought about the disaster are thus re-expressed as an ontological re-arrangement of molecular matter: a shift from the representation of the damaged drilling rig and its gushing crude to the actualisation of a ruinous image.' S. Schuppli, Nature Represents Itself, 2018, http://susanschuppli. com/videos/nature-represents-itself/ (accessed 25 November 2018). See also Schuppli, Slick Images, 2018, http://susanschuppli. com/exhibition/slick-images/ (accessed 1 November 2018) and S. Schuppli, 'Dirty Pictures' in Living Earth: Field Notes from the Dark Ecology Project, 2014-2016 (Amsterdam: Sonic Acts Press, 2016), 189-211.

83 See for instance, Forensic Architecture in collaboration with SITU Research, 'Case: Guatemala'

84 This relationship between the dual senses of representation might be productively read in the context of the 2010 Deepwater Horizon oil spill (see note 82), which has been addressed by Tavares in the context of nonhuman rights and universal jurisdiction (representation as political representation) and by Schuppli both in terms of the political representation of nature and the 'cinematic' or aesthetic representational capacity of the oil spill; see Tavares, 'Nonhuman Rights'; and Schuppli, Nature Represents Itself. 
It is often left to the side that the world is already a sensorium of environmental transformations... This is evident in how black snow expresses pollution in the Artic ... We require a different attention to the world's capacity to represent itself. This is where techno-science enters: the molecular nature of environmental change has been pushing a different sensibility to material properties, acoustics, and chemicals ... All this has been key to feed the discussion of new problems and the constitution of new politics. ${ }^{85}$

This 'constitution of new politics' has been the concern of figures such as Eduardo Viveiros de Castro and the 'postrepresentationalist anthropology' of Anna Tsing or Marisol de la Cadena, as well as proponents of actor-network theory such as Bruno Latour. ${ }^{86}$ Rather than remain in the realm of the general, however, let us begin to unravel this through a particular practice, and in the specific vocabulary of witnessing - or, as we shall see, possible replacements or multispecies synonyms for this term. Here, I turn to a project by Jennifer Gabrys, which, although based in the putative 'West', engages with many key post- and decolonial representational quagmires. Gabrys' work on 'sensing lichens' is part of the London-based Citizen Sense research project (for which Gabrys is principal investigator). The project investigates the relationship between technologies and practices of environmental sensing and citizen engagement. ${ }^{87}$ Part of Gabrys' research concerns 'bioindication': 'a process by which environmental pollution registers in the bodies, inhabitations and relations of organisms.' Recalling the temporality of 'slow violence', bioindicator organisms 'express physiological or other observable changes that can indicate the accumulation or duration of pollution events - or even possible recovery from pollution events. ${ }^{38}$ While previous work focused on moss, the project to which I refer here addresses lichens, which 'are particularly notable for their bioindicator characteristics, and are frequently studied for their ability to signal air and soil pollution. ${ }^{89}$

Gabrys' work opens up a number of avenues relevant to a potential reconceptualisation of the witness. Firstly, rather than mobilise the metaphor of a nature that 'speaks' (as is common in environmental campaigns), and rather than use the generally human-centred noun 'witness', Gabrys refers to lichens as 'bioindicators', thus avoiding anthropomorphising nature or anthropocentrising the 'granting' of rights or 'voice' to the nonhuman. In the context of the prosopopeia of 'forensic speech'

G. Pereira, 'Towards an Environmental Architecture', e-flux Architecture, 20 June 2018, https://www.e-flux.com/architecture/ positions/205375/towards-an-environmental-architecture/ (accessed 1 November 2018).

86 For a useful overview of the literature in deliberative democracy that proposes to extend communicative competence to nonhumans, as well as 'object-oriented democracy' and 'material politics/participation' (inspired by actor-network theory), see L. Disch, 'Ecological Democracy and the Co-Participation of Things' in T. Gabrielson, C. Hall, J. M. Meyer and D. Schlosberg (eds), The Oxford Handbook of Environmental Political Theory (Oxford: Oxford University Press, 2016), 624-641.

87 'Citizen Sensing and Environmental Practice: Assessing Participatory Engagements with Environments through Sensor Technologies' is funded by the European Research Council. See https://citizensense.net.

88 J. Gabrys, 'Sensing Lichens: From Ecological Microcosms to Environmental Subjects', Third Text 151, 32, 2, Spring 2018, 350367 , at 356, emphasis added.

89 Gabrys, 'Sensing Lichens', 352. Lichens are particularly interesting insofar as they are not actually plants; composed of fungi, alga and/or cyanobacteria, they are amalgams of multiple organisms across kingdoms and hence taxonomic categories (352).

90 Weizman, 'Introduction: Forensis', 9. 
'objects are animated in the process of presentation, referred to as if they were human subjects', even if those who do the animating are not only humans but also 'automated or semi-automated technologies of detection and imaging. ${ }^{91}$ While Schuppli retains the term 'witness', albeit prefaced by the qualifier 'material' (with the caveat that the term 'witness' is used rhetorically rather than suggesting that material literally is the author of linguistic speech acts), both Schuppli and Gabrys prioritise the term 'expressive' rather than remaining with a vocabulary limited to 'speech. ${ }^{92}$

Secondly, Gabrys' focus on 'speculative engagements' challenges the notion of any given organism (as witness or otherwise) as an individual. Drawing from Alfred North Whitehead and Isabelle Stengers, Gabrys uses the term 'speculative' to point to 'the distributed capacity of organisms and environments to generate new modes of encounter together with new propositions for ways of being. ${ }^{93}$ This gesture entails remaking environmental subjects and rethinking political entanglements in ways that challenge the notion of both the individual organism and the environment. In an eco-political register, Gabrys draws on Gilbert Simondon's concept of individuation, which refers to 'the ways in which entities are in-formed in relation to each other and their milieus ... This is also to say that what constitutes "human" is not a fixed entity, and can shift in relation to different articulations, relations and milieus.94

Thirdly, in her emphasis on lichens as 'environmental subjects' and participants in 'collective communities engaged in multi-species world-making projects, ${ }^{95} \mathrm{Gabrys}$ provides a useful point of orientation in the abovementioned debates around representation and 'speaking for', here framed through perspective. In this conceptualisation and practice of bioindication, humans are not 'proxy representatives', 'advocates' or 'spokespersons' for natural systems; and the practice of 'citizen science' curbs the condescension of science as an 'expert' and supposedly objective practice. Environmental sensing involves a shift in perspective, with the task being 'to consider how these inverted modes ... might open up other approaches to environmental conflict by encountering pollution from the point of view of other organisms, ${ }^{96}$ and through their 'accounts'. This approach is now common in a wide range of theoretical approaches and practices. ${ }^{97}$ Yet more importantly for the post- or decolonial context, Gabrys argues that 'bioindication through these multiplying points of view also demonstrates how "nature" is not a stable referent.' Rather, drawing from Eduardo Viveiros de Castro's Cannibal Metaphysics: For a Post-Structuralist Anthropology, which draws from Amazonian and Amerindian cosmologies, Gabrys suggests that 'nature' can in fact be understood as 'a realm where diversity multiplies toward a "multinaturalism"”

91 Weizman, 'Introduction: Forensis', 10, emphasis added.

92 Gabrys speaks of the expressive capacities of bioindication or 'expressive organisms', and Schuppli of the 'expressive' qualities of materials.

93 Gabrys, 'Sensing Lichens', 362.

94 Gabrys, 'Sensing Lichens', 362, emphasis in original.

95 Gabrys, 'Sensing Lichens', 352, emphasis added.

96 Gabrys, 'Sensing Lichens', 365, emphasis added.

97 For example, Gabrys refers to Tsing's attention, in The Mushroom at the End of the World, to 'fungal points of view, which might recast encounters with forests, where multiple overlooked "participants" begin to have more marked roles in constituting "social relations with other beings"', as well as to Eduardo Kohn's work on the communicative exchanges and production of 'meaning' between multiple organisms in his How Forests Think. Gabrys, 'Sensing Lichens', 365. 
where ... organisms might also be approached as persons and as having perspectives as persons. ${ }^{98}$ It is in this sense that a new politics might begin to take shape.

As bioindicators, lichens are particularly pertinent to the expanded temporal schema of witnessing and bearing witness that I am suggesting here. Recalling the discussion above regarding how to narrate, visualise or represent environmental violations, the speculative practices that Gabrys refers to 'do not merely "signal" that an event has occurred or is occurring' (that is, in both the past and present). They also materialise relations and processes among and between organisms and ecologies that take place due to the (often slow and otherwise invisible) accumulation of pollutants and environmental changes wrought by extractive and damaging industries. ${ }^{99}$ 'Bearing witness' in this bioindicative register does not entail merely sensing and indicating but also transforming environments in the present and future, across species divides.

\section{Conclusion}

Gabrys' work with lichens suggests that nonhuman forms of life can actively register environmental conditions and form parts of multispecies world-making practices, as well as provide us with alternatives to representational schemas that, however wellintentioned, often end up reinforcing the silencing they seek to correct. Here, the 'witness' (or bioindicator) can be called upon to 'give an account', but also functions in the productively ambiguous space of 'missingness' insofar as the injury borne witness to is often qualitative, ${ }^{100}$ resisting quantitative and classificatory capture. This qualitative aspect also extends into forms and practices of care, nurturing and worldmaking that take place across organism and species divides. Such proactive or creative (rather than merely reactive) practices of care (rather than simply repair) are useful insofar as they undo or disregard the modernist and colonial binaries of nature/culture and subject/object that underlie the deleterious consequences of extractivist governmentality, whereby nature is conceived as worth 'saving' or protecting only insofar as it is profitable to do so for the sake of the human species.

Furthermore, maintaining the language of the witness, using the framework provided by Givoni, allows us to keep hold of witnessing as a distinctive form of ethics and politics. This - more than other forms of activism, advocacy or representational work - entails a practice that simultaneously makes political and empirical claims, and contests the individualism upon which contemporary neoliberal governmentality is premised. This is particularly pertinent in the context of environmental violence and the 'compliance-based environmental management' that Green speaks of, where states often displace responsibility for the work of care and repair onto NGOs and civil society. Here, the world-making evoked by Gabrys, which has a rich heritage in feminist technoscience, allows 'for certain subjects and relations to gain a foothold?. ${ }^{101}$

\footnotetext{
98 Gabrys, 'Sensing Lichens', 365, emphasis added.

99 Gabrys, 'Sensing Lichens', 367.

100 Gabrys, 'Sensing Lichens', 358.

101 Gabrys, 'Sensing Lichens', 352.
} 
Just as 'humanitarian' disasters do not concern merely the human but instead the conditions that sustain life and enable certain (cultural and 'natural') forms of life, and just as the 'rights of nature' are only in part about what we know as 'nature', the world-making practices I refer to are formed across species. ${ }^{102}$ Rather than rights, voice or membership of an environmental public being extended or granted to more-than-humans from a position of anthropocentrism, 'persons' - which I am here extending to 'co-witnesses' - are produced in and by relations between humans and nonhumans. ${ }^{103}$ 